\title{
ISOLATION AND IDENTIFICATION OF CYANOBACTERIA AND ITS IMPACT ON SEED GERMINATION POTENTIAL OF MAIZE (Zea mays L.) USING SEED GERMINATION
EXPERIMENT
}

Krishna Moorthy Sivalingam

Department of Biology,

College of Natural and Computational sciences, Wolaita Sodo University, Wolaita Sodo, Ethiopia.

Abstract - In this present study, 11 different cyanobacterial cultures were isolated and identified from Galba River of Wolaita Sodo Town, Wolaita region, Ethiopia and identified based on the morphometric characters under microscopic examinations. Among these 11 cyanobacterial isolates 10 isolates were identified as non-heterocystous and one isolate was identified as heterocystous cyanobacteria. The identified nonheterocystous cyanobacterial isolates were Pseudanabaena sp. WSU1, Phormidium sp. WSU2, Geitlerinema sp. WSU3, Arthrospira sp. WSU4, Oscillatoria sp. WSU5, Phormidium sp. WSU6, Lyngbya sp. WSU7, Gloeocapsa sp. WSU8, Oscillatoria sp. WSU9, Spirulina sp. WSU10 and the identified heterocystous cyanobacterial isolate was Calothrix sp. WSU11. Formulated Aqueous extracts of all these 11 cyanobacterial isolates at three different concentrations such as $1 \%, 2 \%$ and $3 \%$ were used for seed germination experiment using Zea mays L. (maize) seeds. The non-heterocystous cyanobacterial isolates Pseudanabaena sp. WSU1 at 1\%, Phormidium sp. WSU2 at $2 \%$, Geitlerinema sp. WSU3 at 2\%, Lyngbya sp. WSU7 at $3 \%$, Spirulina sp. WSU10 at $2 \%$ concentration and heterocystous cyanobacterial isolates Calothrix sp. WSU11 at $3 \%$ concentration showed significantly higher results in all the morphological and biochemical parameters of Zea mays L. (maize) when compared to control. The present study results indicated that the application cyanobacterial aqueous extracts influenced the metabolism of reserve food and promoted the seed germination effectively.

Keywords-Cyanobacteria, Aqueous extract, germination, maize

\author{
Kibrom Delfe \\ Department of Biology, \\ College of Natural and Computational sciences, \\ Wolaita Sodo University, Wolaita Sodo, Ethiopia.
}

\section{INTRODUCTION}

Ethiopia is one of the most populated country in Africa with a population of 102.4 million UNICEF (2017). Even though Ethiopia has faster growing economy in the African continent, it still remains poorest World Bank (2017b). The agriculture sector contributing more towards to the poverty reduction. Agriculture sector is the mainstay of the Ethiopian's economy and therefore this sector regulates the growth of all the other sectors and subsequently the whole national economy of Ethiopia. Crop production alone taking $60 \%$ of the agriculture sector's total output whereas livestock $27 \%$ and others taking $13 \%$. While the agriculture sector is an important part of the Ethiopian economy, particularly in rural zones where 55 percent of the women and 83 percent men are working in agriculture sector especially involved in crop cultivations CSA and ICF (2016), World Bank (2017b). This agriculture sector is dominated by small-scale growers engaging old-style technology, adopting a low input and low output production system. This low input and low output concept were followed by farmers usually due to the high cost of chemical fertilizers, low availability and side effects of chemical fertilizers in the soil as well as to the crops. So, the requirement of biofertilizer as an alternative to chemical fertilizer is very urgent to improve the productivity of crops in agriculture sector. Biofertilizers are microorganisms applied as live form to enhance the crop productivity and improve the soil health Different kinds of microorganisms like bacteria, fungi, and algae can be used for the production of biofertilizers (Smith and Read (2008), Lucy et al. (2004), Vessey (2003). Among these various kinds of microorganisms, cyanobacteria placed in a first place.

Cyanobacteria or blue green algae are free living, oxygenic, photosynthetic and nitrogen fixing gram negative prokaryotic microorganisms. Cyanobacteria can produce a different kind 


\section{International Journal of Engineering Applied Sciences and Technology, 2019 Vol. 4, Issue 7, ISSN No. 2455-2143, Pages 65-72 \\ Published Online November 2019 in IJEAST (http://www.ijeast.com)}

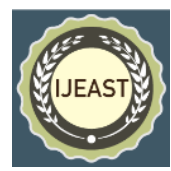

of compounds and products useful to human being. Application these cyanobacteria influences the plant disease resistant, growth and development. Cyanobacteria can be used as biofertilizer in free living nitrogen fixing form as well as symbiotic association form to cultivate several crops worldwide. In addition, application of these cyanobacterial fertilizers is also used to recover the soil fertility, particularly for the retrieval of alkaline soils making them appropriate for the crop cultivation. Cyanobacteria also known to produce various kinds of plant growth promoting substances like cytokinin, gibberellin, auxin and abscisic acid, vitamins, polypeptides and exopolysaccharides which acts as antifungal and antibacterial properties which give disease resistant to the crops. Cyanobacteria can also mobilize the insoluble inorganic phosphate and influences the plant growth. Cyanobacteria have a selective property to survive in a variety of agronomic and ecological conditions Rai et al. (2019), Manu Arora et al. (2010), Karthikeyan et al. (2007).

Maize (Zea mays L.) is one of the important cereal crops cultivated worldwide and maize act as a staple food crop especially in developing countries like Ethiopia Kandil (2013). In the world cereal production, corn is placed as the $3^{\text {rd }}$ major cereal crop after rice and wheat Zamir et al. (2013). White maize is one the major food crop in Ethiopia after tef (Eragrostis tef). Ethiopia ranked fifth largest producer of maize in Africa and 94\% of the crop production is covered by smallholder farmers Mitiku Woldesenbet and Asnakech Haileyesus (2016). All the farmers are depending on chemical fertilizers for maize cultivation. Due to continuous usage and over dosages of chemical fertilizers adversely affect the soil properties which declining the yield directly. So many studies outside Ethiopia have been studied related to plant growth promoting efficiency of cyanobacterial cultures using different crops but very rare in Ethiopia. Therefore, the present study has been majorly focussed on cyanobacterial isolation and identification to evaluate its impact on seed germination potential of maize (Zea mays L.) using seed germination experiment.

\section{MATERIALS AND METHODS}

\section{A. Sample source and sample collection-}

Soil and Water samples were randomly collected from Galba river of Wolaita Sodo Town Southern Ethiopia from the month of December 2017 to January 2018. Samples of visually exposed cyanobacterial growth on underwater plus exposed soils, aquatic plants and pebbles were collected in polythene bags containing native water and brought to the Post Graduate Microbiology Laboratory, Department of Biology, Wolaita Sodo University, Wolaita Sodo, Ethiopia for further process. All the samples were processed within $48 \mathrm{~h}$ of their collection.

\section{$B$. Isolation of cyanobacteria-}

BG-11 medium was used for isolation of cyanobacteria. $1 \mathrm{~g}$ of the soil / cyanobacterial samples will be transferred to sterile $100 \mathrm{ml}$ of BG-11 medium (with nitrate source for nonnitrogen fixing and nitrate-free for nitrogen fixing cyanobacteria) in $250 \mathrm{ml}$ conical flasks. All samples were incubated in growth chamber at $25 \pm 2^{\circ} \mathrm{C}$ with illumination of 15001 ux by cool white $40 \mathrm{~W}$ fluorescent tubes. The flasks were regularly monitored for the cyanobacterial growth. After 1015 days of incubation, when visible algal growth appeared 2-3 wet mounts from each flask will be prepared and observed microscopically using binocular research OLYMPUS MICROSCOPE Model CX21FS1. After the microscopic observation, it was streaked on BG-11 agar media with nitrogen source for non heterocystous forms and without nitrogen source for heterocystous forms. Inoculated plates were incubated in the culture room which was maintained at $25 \pm 2^{\circ} \mathrm{C}$ illuminated with cool white $40 \mathrm{~W}$ fluorescent tubes at an irradiance of 1500 lux with $16 / 8 \mathrm{hrs}$ light and dark cycle. The culture rack was fitted with photoperiodic automatic model timer coupled with room temperature controller to provide alternative light and dark phases. The plates were observed regularly for cyanobacterial growth and isolated filaments of cyanobacteria. Isolation of the cyanobacterial strains was done by randomly picking different types of colonies developed on the BG11 agar media and was examined under binocular research microscope. If growth of heterotrophic bacteria or any other mixed culture was observed under any of the condition after incubation, cyanobacterial colonies were continuously cultured onto fresh BG11 agar medium until uni-cyanobacterial cultures obtained. The entire process was performed aseptically Rippka et al. (1979), Allen and Stanier (1967), Castenholz (1992), Krishna Moorthy et al. (2019). After the isolation of pure algal cultures, the identification was done by the following methods

\section{$C$. Identification of cyanobacteria-}

All the purified cultures were identified by microscopically based on morphometric observation like the length and the width of the vegetative cells also the width of the sheath, type of spores, presence or absence of hormogonia, presence or absence of spores and its position, number of heterocyst and its repetition, presence of aikinites and its type, the nature of cell wall, presence or absence gas vacuoles, as well as pigment color was taken in consideration according to Desikachary (1959), Komárek and Hauer (2013) and Khare et al. (2014), Krishna Moorthy et al. (2019).

\section{Maintenance of isolated cyanobacterial cultures-}

Most widely used method for laboratory maintenance of cultures is by storing them in agar slants. This was done by inoculating pure cultures into a nutrient agar medium which solidified in sterile tubes. All the unialgal strains were maintained at a temperature of $19 \pm 1^{\circ} \mathrm{C}$ under 1500 lux of cool white $40 \mathrm{~W}$ fluorescent tubes. All the strains were maintained in BG-11 agar slants and broth medium. The isolated cyanobacterial cultures were sequentially assigned with reference numbers having its own uniqueness and deposited to fresh water cyanobacterial and microalgae repository of 


\section{International Journal of Engineering Applied Sciences and Technology, 2019 Vol. 4, Issue 7, ISSN No. 2455-2143, Pages 65-72 \\ Published Online November 2019 in IJEAST (http://www.ijeast.com)}

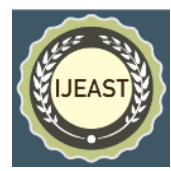

Biology Department, Wolaita Sodo University. The isolated and identified cyanobacterial cultures maintained in repository will be sub cultured for every 3-4 months depending on the culture conditions Krishna Moorthy et al. (2019).

\section{E. Mass Cultivation of cyanobacteria under laboratory condition-}

All the purified cyanobacterial isolates were selected from the culture plates and transferred to $1000 \mathrm{ml}$ capacity culture flasks containing sterilized BG11 media aseptically. The inoculated conical flasks were then incubated under 1500lux (16hrs light 8hrs dark cycle) and at $25 \pm 2^{\circ} \mathrm{C}$ in culture room Rippka et al. (1979). The mass cultured cyanobacterial isolated were harvested after 20-25days of incubation and used for the preparation of aqueous extract Krishna Moorthy et al. (2019).

\section{$F$. Seed germination experiment using plate method-}

The Maize seeds (Zea mays L.) were collected from local market. Seeds were surface sterilized with $70 \%$ ethanol or 0.1 $\% \mathrm{HgCl} 2$ for $3 \mathrm{~min}$. Ten viable seeds in each plat was tested for each cyanobacterial aqueous extract (non-nitrogen fixers and nitrogen fixers). Seeds, without algal extract were served as control. Each Petri dish contain ten surface sterilized seeds was placed on filter paper and moistened with $10 \mathrm{ml}$ of the aqueous extract of cyanobacterial isolates in different concentrations like $1 \%(1 \mathrm{gm} / 100 \mathrm{ml}), 2 \%(2 \mathrm{gm} / 100 \mathrm{ml})$ and $3 \%(3 \mathrm{gm} / 100 \mathrm{ml})$. Petri-dishes containing seeds with $10 \mathrm{ml}$ of distilled water served as a control. The growth parameters including germination percentage, coleoptile length and radicle length as well the biochemical parameters such as carbohydrate and protein content were also recorded on the 2 days interval up to 8 days after incubating seed at $28^{\circ} \mathrm{C}$ Krishna Moorthy et al. (2019), Pitchai et al. (2010).

\section{G. Statistical Analysis-}

The data related morphological and metabolic parameters were exposed to one-way analysis of variance (ANOVA) technique (Origin pro software package 8.0) and mean separations were adjusted by the Multiple Comparison test. Mean were compared by using Fisher's LSD test at $p<0.05$ level of significance. All the data included in the results were presented in mean and standard error $( \pm)$ of mean of three replicates per treatment and repeated three times.

\section{RESULTS AND DISCUSSIONS}

The present research was mainly focused on the collection of cyanobacterial samples, isolation and purification of different cyanobacterial species, identification of cyanobacteria based on the morphological characteristic features, cultivation of isolated cyanobacterial cultures under laboratory conditions and its impact on seed germination potential of maize (Zea mays L.) crops, Wolaita Sodo, Southern Region of Ethiopia from December, 2017 to May, 2018. The results are as follows.

\section{A. Isolation and identification of cyanobacteria}

Isolation of cyanobacteria from soil, aquatic and cyanobacterial samples of Galba River was the first study conducted in study area of Wolaita Sodo Town, Southern Ethiopia. From all the collected samples, total of 11 cyanobacterial species were isolated and identified based on the morphometric characteristic's features using microscope (Table 1). Filamentous and non-heterocystous group of cyanobacteria are predominant and heterocystous were least. Among 11 isolated cyanobacteria species, 10 non-heterocystous cyanobacterial isolates were identified and named as Pseudanabaena sp. WSU1, Phormidium sp. WSU2, Geitlerinema sp. WSU3, Arthrospira sp. WSU4, Oscillatoria sp. WSU5, Phormidium sp. WSU6, Lyngbya sp. WSU7, Gloeocapsa sp. WSU8, Oscillatoria sp. WSU9, Spirulina sp. WSU10 and only one was identified as heterocystous cyanobacterium Calothrix sp. WSU11. The cyanobacterial identification process of current study is similar to the study conducted by Desikachary (1959), Gomont (1982), Komárek and Anagnosti-dis (1998 and 2005). Similarly, Stanier et al. (1978), Castenholz and Waterbury (1989) used morphological, physiological and ecological characteristics for the cyanobacterial identifications. The heterocystous and non-heterocystous cyanobacterial isolates were identified based on the morphological characters using microscope in 10x, 40x magnifications by Mayur Gahlout (2017), Krishna Moorthy et al. (2019).

\begin{tabular}{|c|c|c|}
\hline $\begin{array}{l}\text { Isolate } \\
\text { No. }\end{array}$ & Morphometric characters & $\begin{array}{c}\text { Identified } \\
\text { cyanobacteria }\end{array}$ \\
\hline WSU1 & $\begin{array}{l}\text { Solitary trichomes, no sheathes, occasional motile, less than } \\
30 \text { cells, lack of heterocyst, apical cells are not attenuated, } \\
\text { cells typically cylindrical with cross walls, } 1-3.5 \mu \mathrm{m} \text { wide, } \\
\text { end cells are rounded }\end{array}$ & $\begin{array}{l}\text { Pseudanabaena sp. } \\
\text { WSU1 }\end{array}$ \\
\hline WSU2 & $\begin{array}{l}\text { Bright blue-green trichomes attenuated at the ends, hooked. } \\
\text { Cells shorter than wide, } 3.9-7.1 \mu \mathrm{m} \text { wide, } 1.3-3.8 \mu \mathrm{m} \text { long, } \\
\text { no cross walls, granular cell content. Conical apical cells } \\
\text { without calyptra. }\end{array}$ & $\begin{array}{l}\text { Phormidium sp. } \\
\text { WSU2 }\end{array}$ \\
\hline WSU3 & $\begin{array}{l}\text { Straight filaments with rarely curved, not constricted } \\
\text { septum, cells longer than wide }(3.8-8.2 \times 1.6-2.4 \mu \mathrm{m}) \text {. One } \\
\text { or two beads in the septum; apical cell is cylindrical with } \\
\text { rounded apex. Severe gliding motility with waving and } \\
\text { rotation. }\end{array}$ & $\begin{array}{l}\text { Geitlerinema sp. } \\
\text { WSU3 }\end{array}$ \\
\hline WSU4 & $\begin{array}{l}\text { Non motile solitary filaments with coiled structure, } 22 \mu \mathrm{m} \text { in } \\
\text { distance between the coils, no sheaths. Cells are longer than } \\
\text { wide }(1.7 \mu \mathrm{m} \text { in width), presence of granules, absence of } \\
\text { aerotopes, rounded apical cells. }\end{array}$ & $\begin{array}{l}\text { Arthrospira sp. } \\
\text { WSU4 }\end{array}$ \\
\hline WSU5 & $\begin{array}{l}\text { Unbranched, straight and long filaments without sheath, lack } \\
\text { of akinetes and heterocyst. Cells are shorter than wide and } \\
\text { arranged in a vertical row with conical apical cell. Filaments } \\
\text { are motile with gliding movement. }\end{array}$ & $\begin{array}{l}\text { Oscillatoria sp. } \\
\text { WSU5 }\end{array}$ \\
\hline WSU6 & $\begin{array}{l}\text { Filaments are solitary, flexuous, curved with sheath, highly } \\
\text { motile, attenuated apex. Cells wider than long }(2.6-3.7 \times \\
5.5-7.0 \mu \mathrm{m}) \text {, presence of granules; rounded apical cell with } \\
\text { calyptra. }\end{array}$ & $\begin{array}{l}\text { Phormidium sp. } \\
\text { WSU6 }\end{array}$ \\
\hline WSU7 & $\begin{array}{l}\text { Filaments are blue green, unbranched, un-tapered with cells } \\
\text { shorter than wide, lack of heterocyst, presence of } \\
\text { mucilaginous sheath and presence hormogonia. These } \\
\text { hormogonia released to develop into a new filament. }\end{array}$ & Lyngbya sp. WSU7 \\
\hline WSU8 & $\begin{array}{l}\text { Singles cells but mostly arranged in pairs. Spherical, } \\
\text { hemispherical, oval to slightly elongated cells are found with } \\
\text { granular content, presence of sheath with blue to violet. }\end{array}$ & $\begin{array}{l}\text { Gloeocapsa sp. } \\
\text { WSU8 }\end{array}$ \\
\hline WSU9 & $\begin{array}{l}\text { Straight un branched long filaments without mucous sheath, } \\
\text { lack of heterocyst, equal diameter throughout whole length. } \\
\text { Vertical cell arrangement with conical apical cells. Highly } \\
\text { motile with gliding movement. }\end{array}$ & $\begin{array}{l}\text { Oscillatoria } \text { sp. } \\
\text { WSU9 }\end{array}$ \\
\hline WSU10 & $\begin{array}{l}\text { Coiled motile filament. Individual trichomes comprised of } \\
\text { single cells that spiral down its entire length. }\end{array}$ & $\begin{array}{l}\text { Spirulina sp. } \\
\text { WSU10 }\end{array}$ \\
\hline WSU11 & $\begin{array}{l}\text { Calothrix was identified by its tapering trichomes with } \\
\text { terminal heterocyst. The lower part of the trichome was } \\
\text { surrounded by colorless sheath. Unbranched filaments with } \\
12 \mu \mathrm{m} \text { wide, up to } 120 \mu \mathrm{m} \text { long, cells are shorter than wide, } \\
\text { Trichome are straight sometimes bent, with a distinct hair at } \\
\text { the end. }\end{array}$ & $\begin{array}{l}\text { Calothrix sp. } \\
\quad \text { WSU11 }\end{array}$ \\
\hline
\end{tabular}




\section{International Journal of Engineering Applied Sciences and Technology, 2019 Vol. 4, Issue 7, ISSN No. 2455-2143, Pages 65-72 \\ Published Online November 2019 in IJEAST (http://www.ijeast.com)}

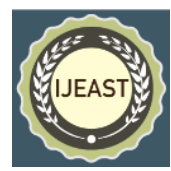

Table. 1. Morphometric characteristics features of cyanobacterial isolates under microscope (40x and 100x oil immersion)

\section{$B$. Impact cyanobacterial isolates on morphological parameters}

The impact in the percentage of seed germination of Zea mays L. seed by different concentrations of aqueous extracts of all the cyanobacterial isolates are showed in the Fig. 1a and Fig.1b. The results in the Fig. 1a and Fig.1b. shows that the seed germination percentage increased progressively throughout the period in all plates inoculated with different cyanobacterial isolates except control. The plates inoculated with cyanobacterial isolates Pseudanabaena sp. WSU1, Phormidium sp. WSU2, Geitlerinema sp. WSU3, Lyngbya sp. WSU7, Spirulina sp. WSU10 and Calothrix sp. WSU11 (Heterocystous) reached maximum of $100 \%$ in the $6^{\text {th }}$ day of incubation at respective concentrations of $1 \%, 2 \%, 2 \%, 3 \%$, $2 \%$, and $3 \%$ of aqueous extracts. The cyanobacterial isolates Arthrospira sp. WSU4, Oscillatoria sp. WSU5, Gloeocapsa sp. WSU8 and Oscillatoria sp. WSU9 reached $100 \%$ level of seed germination only in the $8^{\text {th }}$ day of incubation while the cyanobacterial isolate Phormidium sp. WSU6 showed maximum of $90 \%$ level of seed germination even in the $8^{\text {th }}$ day.

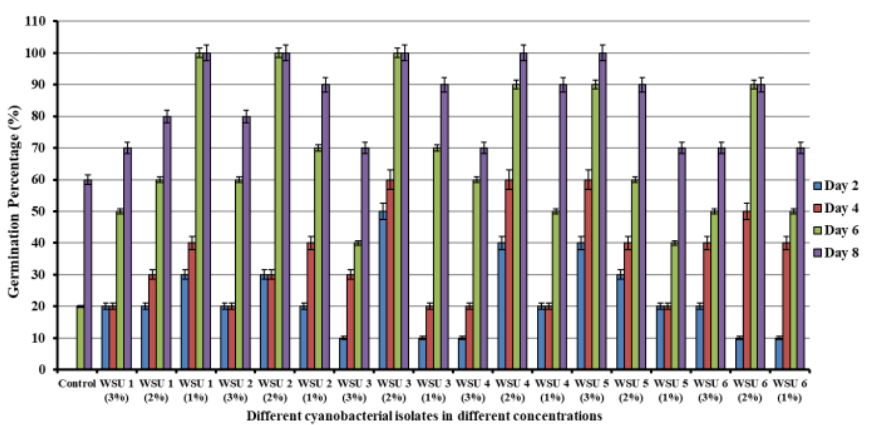

\# Data are the means of three replicates and Error bars represent the standard errors of the means WSU1 - Pseudanabaena sp. WSU1; WSU2 - Phormidium sp. WSU2; WSU3 - Geitlerinema sp. WSU3; WSU4 - Arthrospira sp. WSU4; WSU5 - Oscillatoria sp. WSU5; WSU6 - Phormidium sp. WSU6; WSU - Wolaita Sodo University

Fig. 1a. Effect of aqueous extract of cyanobacterial isolates on percentage of seed germination of Zea mays L. under seed germination experiment $\left(8^{\text {th }}\right.$ day)

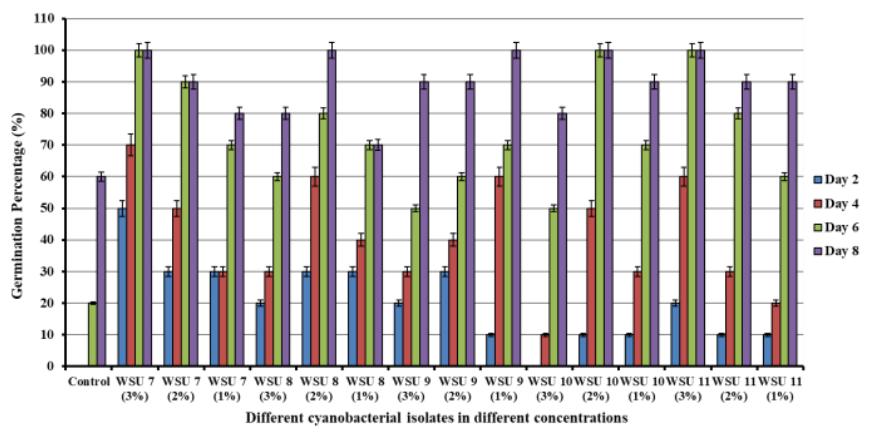

\# Data are the means of three replicates and Error bars represent the standard errors of the means WSU7 - Lyngbya sp. WSU7; WSU8 - Gloeocapsa sp. WSU8; WSU9 - Oscillatoria sp. WSU9, WSU7 - Lyngbya sp. WSU7; WSU8 - Gloeocapsa sp. WSU8; WSU9 - Oscillatoria sp. W
WSU10 - Spirulina sp. WSU10; WSU11 - Calothrix sp. WSU11; WSU - Wolaita Sodo University
Fig. 1b. Effect of aqueous extract of cyanobacterial isolates on percentage of seed germination of Zea mays L. under seed germination experiment ( $8^{\text {th }}$ day)

The percentage of seed germination in control reached maximum of $60 \%$ even in the $8^{\text {th }}$ day of incubation while all the cyanobacterial isolates in all concentrations showed significantly higher level of seed germination percentage than control treatment. The cause for this great response is naturally cyanobacteria can release the plant growth regulators (PGR) like cytokinin, auxins and gibberellins. This PGR directly involved in the seed germination and increased the percentage of seed germination. This result was highly supported by Osman et al. (2010), who reported that the cyanobacteria play a main role in the in the seed germination by releasing phytohormones like gibberellins, auxins and cytokinin. Similarly, the different concentrations (1\% - 10\%) of cyanobacterial extracts encouraged the earlier germination of Pisum sativum L. seeds than control which treated with only distilled water Gayathri et al. (2017). Similar to the present study results was obtained by Mayur et al. (2017) who reported that the application of cyanobacterial cultures such as Gloeocapsa spp., Oscillatoria spp., Aphanocapsa spp., Closterium spp., Rivularia spp., Nostoc spp., and Anabaena spp., showed great impact on the germination status of wheat as well as mung.

The changes in the radicle length are showed in the Fig. 2a and Fig. 2b. The highest radicle length $(7.1+0.437 \mathrm{~cm})$ was observed in the petriplates inoculated with $3 \%$ concentration of heterocystous cyanobacterial isolates Calothrix sp. WSU11 and the lowest radicle length $(0.9 \pm 0.212 \mathrm{~cm})$ was observed in the control plates inoculated with distilled water on $8^{\text {th }}$ day.

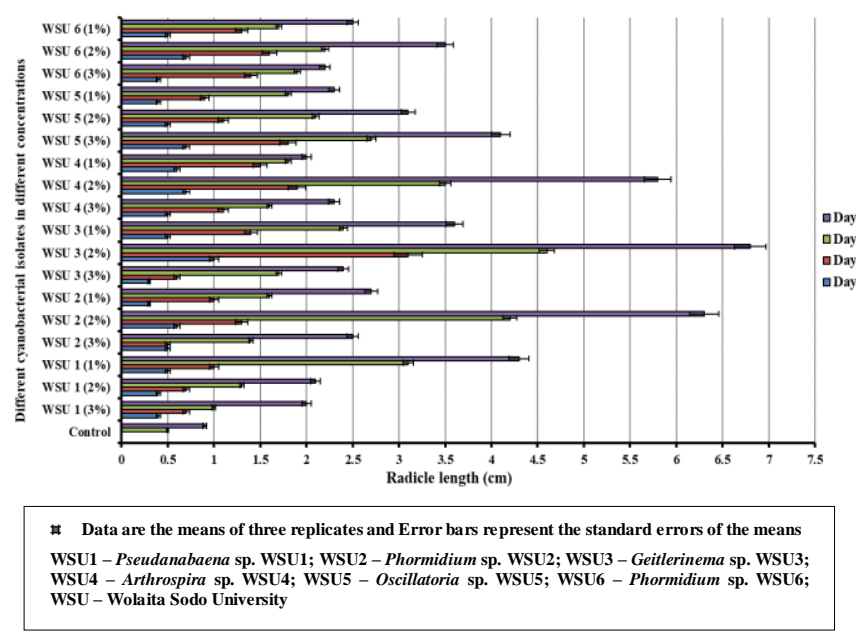

Fig. 2a. Effect of aqueous extract of cyanobacterial isolates on radicle length of Zea mays L. under seed germination experiment ( $8^{\text {th }}$ day) 


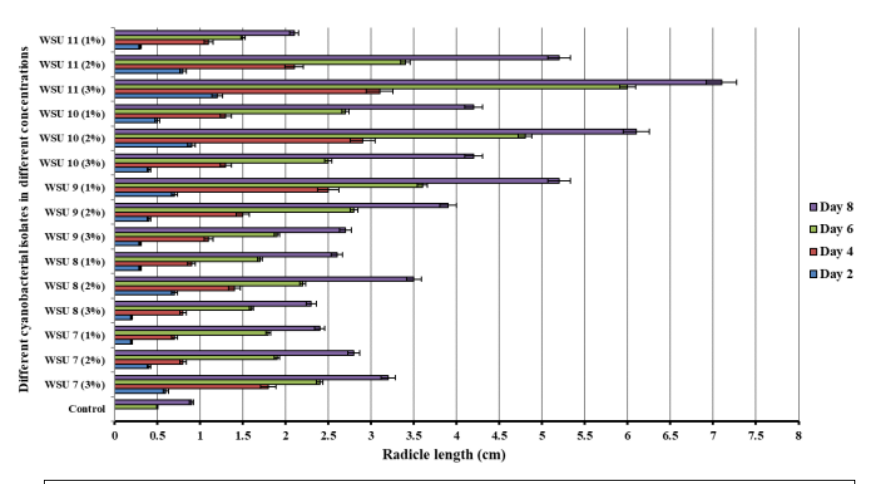

\# Data are the means of three replicates and Error bars represent the standard errors of the means WSU7 - Lyngbya sp. WSU7; WSU8 - Gloeocapsa sp. WSU8; WSU9 - Oscillatoria sp. WSU9; WSU7 - Lyngbya sp. WSU7; WSU8 - Gloeocapsa sp. WSU8; WSU9 - Oscillatoria sp. W.
WSU10 - Spirulina sp. WSU10; WSU11 - Calothrix sp. WSU11; WSU - Wolaita Sodo University

Fig. 2b. Effect of aqueous extract of cyanobacterial isolates on radicle length of Zea mays L. under seed germination experiment ( $8^{\text {th }}$ day)

The radicle length of $6.8 \pm 0.237 \mathrm{~cm}$ was observed in the plates inoculated with Geitlerinema sp. WSU3 nonheterocystous cyanobacterial isolate at 2\% concentration followed by Phormidium sp. WSU2 at 2\%, Spirulina sp. WSU10 at 2\%, Arthrospira sp. WSU4 at 2, Oscillatoria sp. WSU9 at 1\%, Pseudanabaena sp. WSU1 at 1\%, Oscillatoria sp. WSU5 at 3\%, Gloeocapsa sp. WSU8 at 2\%, Phormidium sp. WSU6 at 2\%, and Lyngbya sp. WSU7 at 3\% concentration with respective radicle length of $6.3 \pm 0.157 \mathrm{~cm}, 6.1 \pm 0.411 \mathrm{~cm}$, $5.8 \pm 0.137 \mathrm{~cm}, 5.2 \pm 0.200 \mathrm{~cm}, 4.3 \pm 0.421 \mathrm{~cm}, 4.1 \pm 0.331 \mathrm{~m}, 3.5 \pm$ $0.4 \overline{3} 7 \mathrm{~cm}, 3.5 \pm 0.202 \mathrm{~cm}$ and $3.2 \pm 0.137 \mathrm{~cm}$ (Fig. $2 \mathrm{a}$ and Fig. $2 \mathrm{~b}$ ). The treatment with heterocystous cyanobacterial isolates WSU11 with $3 \%$ level of concentration showed significantly higher in radicle length than control and all other cyanobacterial treatment with all other concentrations on $8^{\text {th }}$ day of incubation. The changes in the radicle length of maize seed was stimulated by the presence of phytohormones in the aqueous extracts of cyanobacterial isolates. This result was supported by several other similar studies done by Osman et al. (2010) reported that several species of cyanobacteria play serious role in the germination process by releasing bioactive elements such as auxins, gibberellins, cytokinin, vitamins, amino acids, and peptides etc. Similarly, the study done by Krishna Moorthy et al. (2019) who reported that the three cyanobacterial isolates such as Pseudanabaena spp. AK-1, Lyngbya spp.AK-2 and Geitlerinema spp. AK-3 showed best results in case of radicle length, coleoptile length and epicotyl length of rend beans when compared control seeds treated with only distilled water.

The changes in the percentage of coleoptile length of Zea mays L. seed by different concentrations of aqueous extracts of all the cyanobacterial isolates are showed in the Fig. 3a and Fig.3b. The very least coleoptile length $(1 \pm 0.437 \mathrm{~cm} \mathrm{~cm})$ of $Z$. mays L. seed was observed in the control when compared to all other treatments with all concentrations even at $2^{\text {nd }}, 4^{\text {th }}, 6^{\text {th }}$ and $8^{\text {th }}$ day of incubation. The coleoptile length $(4.2 \pm 0.135 \mathrm{~cm})$ of Z. mays L. seed treated with aqueous extract of heterocystous cyanobacterial isolate Calothrix sp. WSU11 at 3\% concentration showed significantly higher result when compared to coleoptile length $(1.0 \pm 0.437 \mathrm{~cm})$ of control and all other non-heterocystous cyanobacterial isolates Pseudanabaena sp. WSU1, Phormidium sp. WSU2, Arthrospira sp. WSU4, Oscillatoria sp. WSU5, Phormidium sp. WSU6, Lyngbya sp. WSU7, Gloeocapsa sp. WSU8, Oscillatoria sp. WSU9 and Spirulina sp. WSU10 in all concentrations on $8^{\text {th }}$ day with respective values of $2.8 \pm 0.037 \mathrm{~cm}, 3.8 \pm 0.421 \mathrm{~cm}, 3.7 \pm 0.207 \mathrm{~cm}, 2.8 \pm 0.175 \mathrm{~cm}$, $3.3 \pm 0.227 \mathrm{~cm}, 3.1 \pm 0.332 \mathrm{~cm}, 1.8 \pm 0.234 \mathrm{~cm}, 2.5 \pm 0.421 \mathrm{~cm}$ and $3.7 \pm 0.230 \mathrm{~cm}$ (Fig. 3a and Fig.3b.). Current study result was similar to the study done by Gayathri et al. (2017) who reported that the extracts of Scytonema bohneri (80\%), Dolichospermum spiroides (70\%), Aphanothece stagnina (66.6\%), Calothrix sp. MBDU 901 (66.6\%) and Nostoc microscopicum $(56.6 \%)$ showed higher response in case of seed germination, radicle and plumule length than control (53.3\%). Similarly, the applications of cyanobacterial cultures Pseudanabaena spp. AK-1, Lyngbya spp. AK-2 and Geitlerinema spp. AK-3 in different concentrations (1\%, 2\%, $3 \%)$ showed significant impact on the coleoptile length of Phaseolus vulgaris L. seeds Krishna Moorthy et al. (2019).

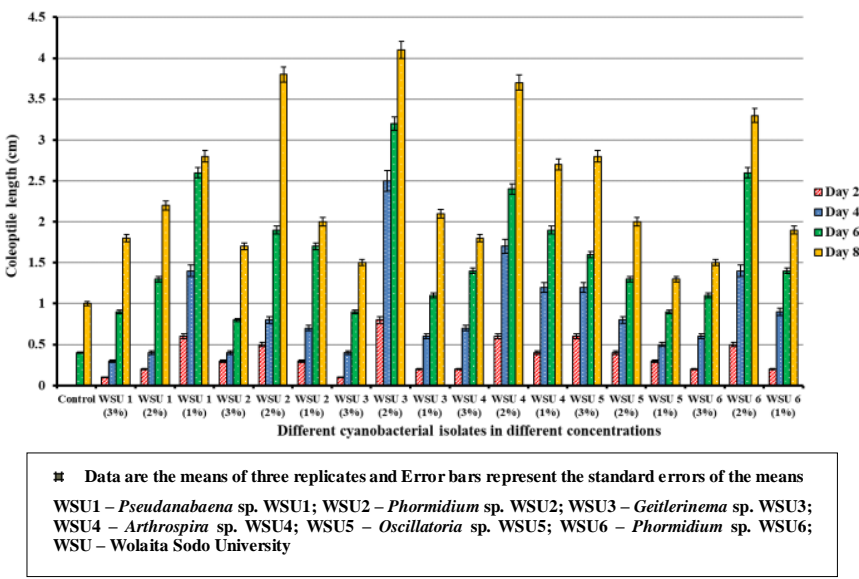

Fig. 3a. Effect of aqueous extract of cyanobacterial isolates on coleoptile length of Zea mays L. under seed germination experiment ( $8^{\text {th }}$ day)

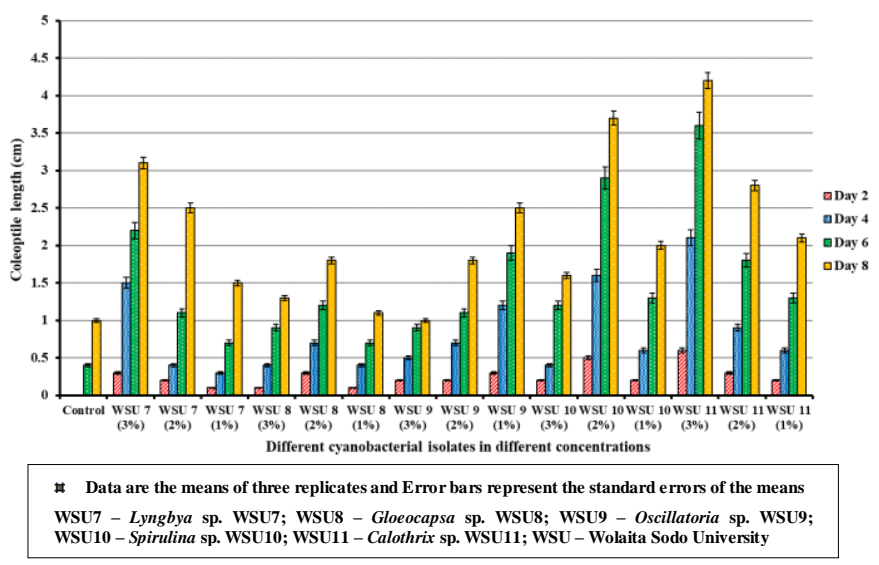




\section{International Journal of Engineering Applied Sciences and Technology, 2019 Vol. 4, Issue 7, ISSN No. 2455-2143, Pages 65-72 \\ Published Online November 2019 in IJEAST (http://www.ijeast.com)}

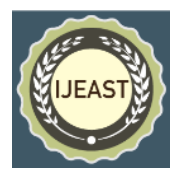

Fig. 3b. Effect of aqueous extract of cyanobacterial isolates on coleoptile length of Zea mays L. under seed germination experiment $\left(8^{\text {th }}\right.$ day)

\section{Impact of cyanobacterial isolates on the biochemical parameters}

Protein is one of the reserve foods in the Z. mays L. seeds. All the stored forms of reserved foods are hydrolysed during the germination process. Hence, the study about protein changes in the seed germination experiments is more important. Here in this present research, protein changes in seeds from all the experiments were analysed properly and presented in the forms of Fig. 4a and Fig.4b. The protein contents of Z. mays L. seeds in the control treatment was not decreased much from $0^{\text {th }}$ day to $8^{\text {th }}$ day. The maximum level of protein reduction was observed in the seeds treated with Geitlerinema sp. WSU3 at $2 \%$ level of concentration followed by Calothrix sp. WSU11 at $3 \%$, Phormidium sp. WSU2 at $2 \%$, Oscillatoria sp. WSU9 at $1 \%$, and Pseudanabaena sp. WSU1 at $1 \%$ which was significantly higher than control and all the cyanobacterial aqueous extracts (Fig. $4 \mathrm{a}$ and Fig.4b).
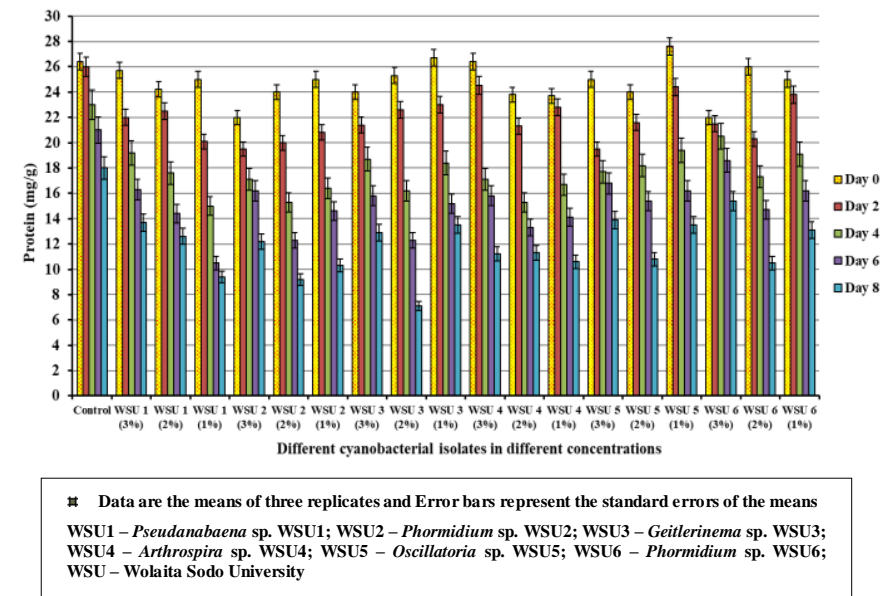

4a. Effect of aqueous extract of cyanobacterial isolates on protein content of Zea mays L. under seed germination experiment $\left(8^{\text {th }}\right.$ day)

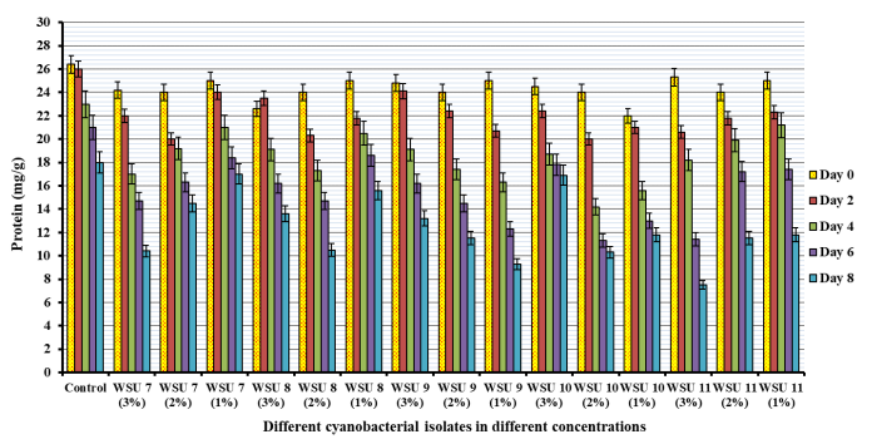

\# Data are the means of three replicates and Error bars represent the standard errors of the means WSU7 - Lyngbya sp. WSU7; WSU8 - Gloeocapsa sp. WSU8; WSU9 - Oscillatoria sp. WSU WSU10 - Spirulina sp. WSU10; WSU11 - Calothrix sp. WSU11; WSU - Wolaita Sodo University 4b. Effect of aqueous extract of cyanobacterial isolates on protein content of Zea mays L. under seed germination experiment ( $8^{\text {th }}$ day)

The changes in the carbohydrate content of control was significantly lesser than all other treatments in all the concentrations even at the $8^{\text {th }}$ day incubation. The maximum amount of carbohydrate reduction was observed in the treatment of WSU3 (Geitlerinema sp. WSU3) and WSU2 (Phormidium sp. WSU2) at $2 \%$ level of concentrations which is significantly higher than control and all other treatments in all concentrations except WSU11 (Calothrix sp. WSU11) at $3 \%$ and WSU2 (Phormidium sp. WSU2) at $1 \%$ concentrations on $8^{\text {th }}$ day of incubation (Fig. 5a and Fig. 5b). On seed hydration, the seeds containing protein and carbohydrates acted as energy sources. So, during the seed germination all these protein and carbohydrate based reserved food materials may be hydrolyzed by hydrolytic enzymes and converted in to simple available form for embryo uptake. So, during the seed starts to germinate, the protein and carbohydrates level will be reduced automatically. The present study is supported by Salisbury and Ross (1991) who reported that the seed germination stimulated many metabolic activities such as secretion and activation of hydrolytic enzymes which caused in breaking down of stored carbohydrates, proteins and other stored materials into available simple form for embryo development.

Similar to the present study results, the research done by Krishna Moorthy et al. (2019) showed the protein and carbohydrate contents of Phaseolus vulgaris $\mathrm{L}$ seeds in the control treatment was not decreased in high level from $0^{\text {th }}$ day to $8^{\text {th }}$ day. The maximum level of protein and carbohydrate reduction was observed in the seeds treated with Geitlerinema sp. AK-3 at 2\% concentration level of concentration followed by Pseudanabaena spp. AK-1 at 3\% concentration and Lyngbya spp. AK-2 at 3\% concentration

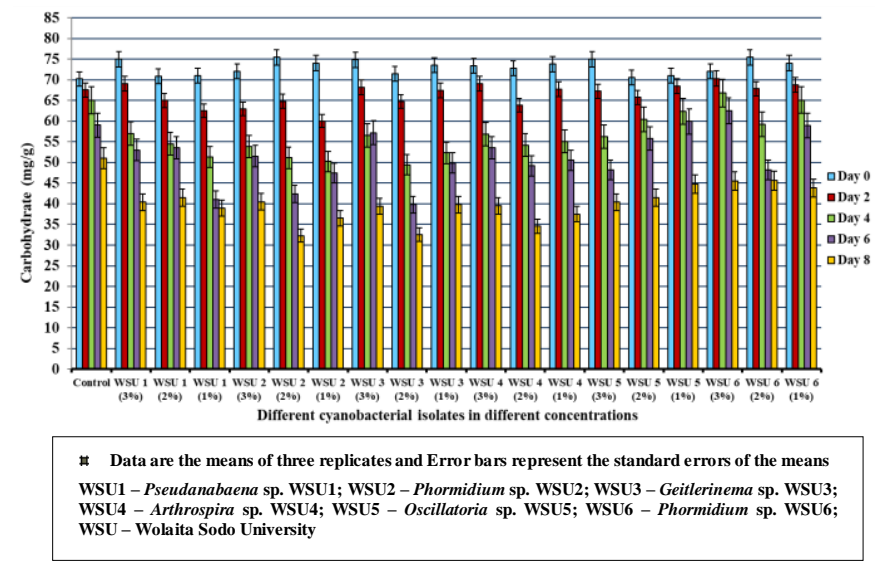

Fig. 5a. Effect of aqueous extract of cyanobacterial isolates on carbohydrate content of Zea mays L. under seed germination experiment ( $8^{\text {th }}$ day) 


\section{International Journal of Engineering Applied Sciences and Technology, 2019 Vol. 4, Issue 7, ISSN No. 2455-2143, Pages 65-72 \\ Published Online November 2019 in IJEAST (http://www.ijeast.com)}

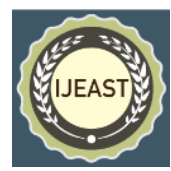

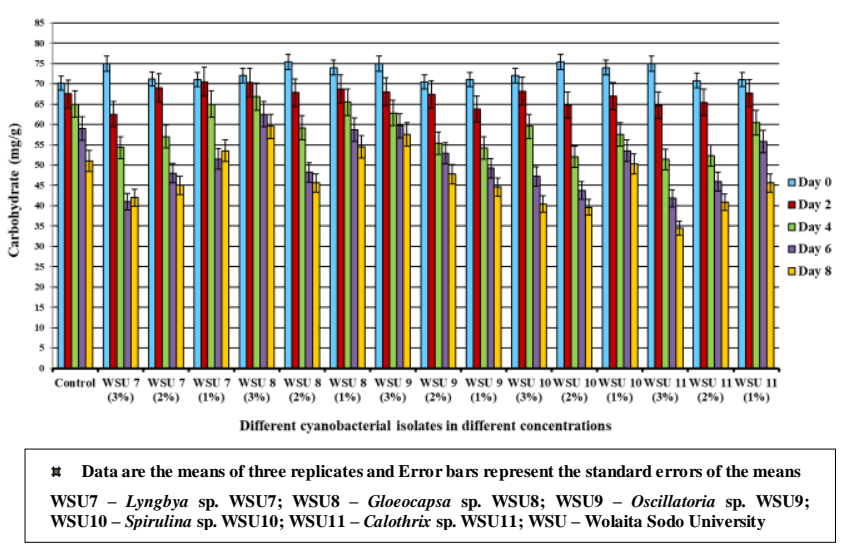

Fig. 5b. Effect of aqueous extract of cyanobacterial isolates on carbohydrate content of Zea mays L. under seed germination experiment $\left(8^{\text {th }}\right.$ day)

\section{CONCLUSION}

Based on the above said results, the non-heterocystous cyanobacteria are more dominant than heterocystous cyanobacteria in the Galba river of Wolaita Sodo Town Southern Ethiopia. The non-heterocystous cyanobacterial isolates Geitlerinema sp. WSU3 at $2 \%$ concentration and heterocystous cyanobacterial isolates Calothrix sp. WSU11 at $3 \%$ concentration showed immediate response and reached $100 \%$ of germination, faster development in the radicle and coleoptile length even on the $6^{\text {th }}$ day of incubation. Similarly, the stored food materials such as protein and carbohydrate content were hydrolyzed maximum in the seeds treated by non-heterocystous cyanobacterial isolate Geitlerinema sp. WSU3 at $2 \%$ concentration and heterocystous cyanobacterial isolates Calothrix sp. WSU11 at 3\% concentration. Therefore, the present study has been concluded that the application of non-heterocystous cyanobacterium Geitlerinema sp. WSU3 at $2 \%$ concentration and heterocystous cyanobacterial isolates Calothrix sp. WSU11 at 3\% concentration can be used as effective liquid fertilizers for the pretreatment of Zea mays L. seed.

\section{ACKNOWLEDGEMENT}

The authors would like to gratefully acknowledge the Post Graduate Microbiology Laboratory, Department of Biology, College of Natural and Computational Sciences, Wolaita Sodo University for providing us the facility to do the research successfully.

\section{REFERENCE}

[1] UNICEF. (2017). The State of the World's Children 2017. Available at: https://www.unicef.org/sowc/.

[2] World Bank. (2017b). Ethiopia Country Overview. Available http://www.worldbank.org/en/country/ethiopia/overview
[3] Central Statistical Agency (CSA) [Ethiopia] and ICF International. (2016). Ethiopia Demographic and Health Survey 2016. Addis Ababa, Ethiopia, and Rockville, Maryland, USA: CSA and ICF.

[4] Smith S.E., and Read D.J. (2008). Mycorrhizal symbiosis, 3rd edn. Academic Press.

[5] Lucy M., Reed E., and Glick B.R. (2004). Applications of free-living plant growth-promoting rhizobacteria, Antonie van Leeuwenhoek. Vol.86, (pp.1-25).

[6] Vessey J.K. (2003). Plant growth promoting rhizobacteria as biofertilizers, Plant Soil. Vol.255, (pp.571-586).

[7] Rai A.N., Singh A.K., and Syiem M.B. (2019). Cyanobacteria: From Basic Science to Applications, Springer, chapter 23, (pp.459-476).

[8] Manu Arora, Kaushik A., Nisha Rani and Kaushik C.P. (2010). Effect of cyanobacterial exopolysaccharides on salt stress alleviation and seed germination, J. Environ. Biol., Vol.31, No.5, (pp.701 704).

[9] Karthikeyan N., Prasanna R., Lata and Kaushik B.D. (2007). Evaluating the potential of plant growth promoting cyanobacteria as inoculants for Wheat, Eur. J. Soil Biol., Vol.43, (pp.23 20).

[10] Kandil E.E. (2013). Response of Some Maize Hybrids (Zea mays L.) to Different Levels of Nitrogenous Fertilization, Journal of Applied Sciences Research, Vol.9, No.3, (pp.1902-1908).

[11] Zamir M.S.I., Yasin G., Javeed H.M.R., Ahmad A.U.H., Tanveer A., and Yaseen M. (2013). Effect of different sowing techniques and mulches on the growth and yield behavior of spring planted maize (Zea mays L.), Cercetări Agronomice în Moldova, Vol.1, No.153, (pp.77-82).

[12] Mitiku Woldesenbet and Asnakech Haileyesus. (2016). Effect of nitrogen fertilizer on growth, yield and yield components of maize (Zea mays L.) In Decha District, Wouthwestern Ethiopia, International Journal of Research - GRANTHAALAYAH, Vol.4, No.2, (pp. 95100).

[13] Rippka R., Deruelles J., Waterbury J.B., Herdman M., and Stanier R.Y. (1979). Generic assignments, strain histories and properties of pure cultures of cyanobacteria, J. Gen. Microbiol. Vol.111, (pp.1-61).

[14] Allen M.M., and Stanier R.Y. (1967). Selective isolation of Blue-Green algae from water and soil, J. gen. Microbiol. Vol.5I, (pp.203-209).

[15] Castenholz R.W. (1992). Species usage, concept, and evolution in the cyanobacteria (blue-green algae), Journal of Phycology, Vol.28, (pp.737-745).

[16] Desikachary T.V. (1959). Cyanophyta, ICAR Monograph on Algae, ICAR, New Delhi, (Pp. 686).

[17] Komarek J., and Hauer T. (2013). CyanoDB.cz - On-line database of cyanobacterial genera. Univ. of South Bohemia and Inst. of Botany AS CR., Available at http://www.cyanodb.cz.

[18] Khare P., Singh A., Prabha C., and Kumari S. (2014). Study of Cyanobacterial Biodiversity in Rice Fields of 
Central Bihar, 3rd World Conference on Applied Sciences, Engineering and Technology, Kathmandu, Nepal, (pp. 27-29).

[19] Krishna Moorthy S., Aberham Kassahun, Ermias Dereje and Adanech Tomas. (2019). Isolation and Identification of Blue Green Algae and Its Plant Growth Promoting Efficacy using Red Kidney Beans (Phaseolus vulgaris L.) by Seed Germination Experiment, J. Algal Biomass Utln, Vol.10, No.2, (pp.52-59).

[20] Pitchai Palaniappan., Malliga P., Manian K., Sivaramakrishnan S., Madhaiyan S., and Tongmin S.A. (2010). Plant growth promontory effect on cow pea (Vigna unguiculata) using coir pith aqueous extract formulation of Cyanobacterium Phormidium. Am.-Eur. J. Agric. Environ., Vol.8, No.2, (pp.178-184).

[21] Gomont M. (1982). Monographie des Oscillariées (Nostocacées Homocystées). Deuxième partie. Lyngbyées. Annales des Sciences Naturelles, Botanique, Vol.7, No.16, (pp.91-264).

[22] Komárek J., and Anagnostidis K. (1998). Cyanoprokaryota1. Chroococcales. - In: Ettl H., Gärtner G., Heynig H.\& Mollenhauer D. (eds), Süsswasserflora von Mitteleuropa 19/1, Gustav Fischer, Jena-StuttgartLübeck-Ulm, (p. 548).

[23] Komárek J., and Anagnostidis K. (2005). Cyanoprokaryota. 2. Oscillatoriales". - In: Büdel B., Krienitz L., Gärtner G. \& Schagerl M. (eds), Süsswasserflora von Mitteleuropa 19/2, Elsevier/Spektrum, Heidelberg, (p. 759).

[24] Castenholz R.W., and Waterbury J.B. (1989). Group I. Cyanobacteria. In Bergey's Manual of Systematic Bacteriology, Edited by N. R. Krieg \& J. G. Holt. Baltimore: Williams \& Wilkins, Vol. 3, (pp.1710-1728).

[25] Mayur Gahlout, Hiren Prajapati, Poonam Chauahan, Rathod Himita kumari and Juhikapatel. (2017). Isolation, Identification and Evaluation of Seed Germination Efficiency of Cyanobacterial Isolates, International Journal of Research and Scientific Innovation (IJRSI), Vol.4, No.4, (pp.64-68).

[26] Osman M.E.H., El-Sheekh M.M., El-Naggar A.H., and Gheda S.F. (2010). Effect of two species of cyanobacteria as biofertilizers on some metabolic activities, growth, and yield of pea plant, Biol. Fertil. Soils, Vol.46, (pp.861875).

[27] Gayathri Manickam, Sumathy Shunmugam, Nooruddin Thajuddin, Gangatharan Muralitharan. (2017). Phytohormones and free volatile fatty acids from cyanobacterial biomass wet extract (BWE) elicit plant growth promotion, Algal Research. Vol.26, (pp.56-64).

[28] Salisbury F.B., and Ross C.W. (1991). Plant Physiology" 4th ed. Belmont, California, USA: Wadsworth Publishing Company, (pp.481). 